\title{
原発再稼働賛否意見の変容に及ぼす受講者の専門性や学習状況, 及び教員意識の影響
}

\author{
高野拓樹 *・乾 明紀 $・$ 加藤千恵・酒井浩二 \\ Influence of student's expertise, learning situations and the teacher's \\ consciousness on opinion fluctuation regarding the pros and cons of restarting \\ nuclear power plants
}

Hiroki TAKANO*, Akinori INUI, Chie KATO and Koji SAKAI

摘 要

本研究では, 政治的リテラシー養成の観点から論争的問題を取り扱う科目「シチズンシップ」で得ら れた結果を元に, 原発再稼働賛否意見の変容に対する受講者の専門性や学習状況, 及び講義担当教員の 意識の影響について検討した。その結果, 講義を通じた賛否割合の変化の度合い（標準偏差：S）は学 科により異なり, 理系を中心に学ぶ学科の方が小さい傾向にあった。また, 大学入学時におけるプレー スメントテスト (英語) の平均点が高い学科, すなわち学習経験が豊富であろう学生が所属する学科ほ ど標準偏差に小さい傾向が見られ，これらは負の相関を示した $(S=7.3 \sim 24.1, r=-0.438)$ 。そして, 原 発再稼働について明確な反対意見をもっている教員のクラスについては, 受講者の賛否割合の変容が小 さく $(S=5.3)$, 常に反対割合が高い状態を維持していた。さらに, 講義スタイルについては, 講義内容 を力を込めて説明する傾向がある教員のクラスは, 淡々と説明することもある他教員のクラスよりも受 講者の賛否変容が大きい傾向 $(S=16.6)$ にあった。このように, 受講者の専門性や学習状況, 及び教員 の意識等によって, 受講者の原発再稼働に対する意見に影響する可能性があることを明らかにした。以 上の結果は, 論争的問題を取り扱うシティズンシップ教育において, これらの影響因子を考慮に入れた 教授法についての更なる検討の必要性を示唆している。

\begin{abstract}
In this study, we investigated the influence of student's expertise, learning situations and the teacher's consciousness on opinion fluctuation regarding the pros and cons of restarting nuclear power plants. Results were obtained from observations of discussions of controversial issues involving the concept of "citizenship" from the perspective of the formation of political literacy. In terms of the degree of change in the ratio of pros to cons, the standard deviation $(\mathrm{S})$ differed depending on academic department, which of departments focus on science tended to be smaller than departments of letters. And, in departments that were higher average score of placement test "English", that is departments in which students had a wealth of learning experience, the standard deviation tended to be small and these results were negative correlation $(\mathrm{S}=7.3 \sim 24.1$, $\mathrm{r}=-0.438$ ). In addition, in a class where a teacher had an explicit dissenting opinion about restarting nuclear power plants, the degree of change in the ratio of pros to cons was small $(S=5.3)$; the high ratio of dissenting
\end{abstract}

京都光華女子大学キャリア形成学部, = 615-0082 京都市右京区西京極葛野町 38

*連絡責任者 : h-takano@mail.koka.ac.jp 
opinion was maintained. In terms of lecture style, in a class where a teacher lectured emphatically (as opposed to in a calm or detached demeanor), there tended to be a larger degree of change in the ratio of pros to cons $(S=16.6)$. In this way, the data demonstrated the possibility of influencing a student's expertise, learning situations and teacher's consciousness on opinion fluctuation regarding the pros or cons of restarting nuclear power plants. These results suggest the importance of further investigation into teaching methods that might be influential in citizenship education dealing with controversial issues.

Key words : Restart of nuclear power plants, Citizenship, Controversial issues, Teacher's consciousness, Student's expertise and learning situations

\section{1. 福島原発事故後の現状と原発再稼働賛否の 調查・研究動向}

2011 年 3 月 11 日に発生した東日本大震災によ る道路や鉄道などのインフラ被害は，政府が定め た復興期間の最初の 5 年間（集中復興期間 : 2011 〜2015 年度）で 95\%以上が復旧したとされてい る。また, 仮設住宅は 2018 年 11 月時点でピーク 時の 9 割以上が減少した。しかし，2019 年 10 月 9 日時点で約 4 万 9000 人が避難を続けている（復 興庁, 2019)。特に, 福島第一原発周辺では, 避難 指示の区域は徐々に縮小しているものの, 指示が 解除された 10 市町村の帰還率は $26.8 \%$ に留まっ ている（産経新聞, 2019）。今井（2016）の報告に よると，「震災前にいた地域に帰りたいですか」, という質問に対し,「元のまちに戻っても帰りたく ない $(16.5 \%) 」 「$ 元のまちに戻らないから帰りた くない $(25.6 \%) 」 と 4$ 割以上の元住民が州りたく ないと回答し, 帰還を阻害する要因として, 住宅 が住める状態になっていないことや, 空間放射線 量值に対する懸念をあげていた。

福島第一原発事故の後, 日本の全ての原子力発 電所 (以下, 原発) について検査が行われ, 2012 年に発足した原子力規制委員会が定めた新規制基 準をクリアした原発だけがその再稼働を許される こととなったため, 2013 年 9 月以降全ての原発が 停止していたが，基準を満たした原発が 2015 年 8 月以降に再稼働している。2018 年 7 月に発表され た第 5 次エネルギー基本計画では, 日本のエネル ギー自給率向上を主目的として, 電源構成比率に占 める原発の割合は 20～22\%を掲げている（資源工 ネルギー庁 2018a)。しかし, 再稼㗢については, 反 対する地域住民と推進する電力会社の裁判にまで
発展し, 地方裁判所で再稼働の差し止め仮処分が 決定した後, 高等裁判所でその差し止めが取り消 されるなど, 混迷を極める状況が続いている。この ような原発再稼働賛否については,いくつかの先行 調査·研究がある。まず, 資源エネルギー庁がまと めた代表的な新聞 5 社の世論調査では, 福島原発 事故後の 2012 年から 2017 年の間，反対が 50 $60 \%$, 賛成が 20〜 40\%であり, 反対が賛成を上回 る状況が続いている（資源エネルギー庁，2017）。 一方, 原発が生活エリアに立地する島根県松江市 では, 雇用等の生活経済面の理由から, 居住地が 原発に近い程, 賛成意見が増えるという報告があ る（片岡ら，2015）。また，同地域における調査に おいて, 再稼働賛成派と反対派の意識構造の違い も明らかにされている（上園ら，2012）。そして, 八ッ橋（2013）は, 原発再稼働の賛否を決める要 因として, 賛成派の「経済要請重視」と反対派の 「持続社会重視」という 2 つの意見が拮抗状態にあ ることを指摘している。このように, 原発再稼働賛 否の現状を調査した複数の報告はある。しかし, ど のような情報をもって, その判断を下したかという 賛否決定に至るプロセスについては報告がなかっ た。そこで著者らは, 大学の講義毎に, エネルギー に関する様々な情報を受講者に提供し, その都度, 賛否意見を調査することで，意思決定における変 容プロセスを明らかにした（高野ら，2018a）。

\section{2. これまでの研究と本研究の目的}

\section{1 これまでの研究ーシティズンシップ 1) 教育 の重要性一}

著者らが原発再稼働の賛否をテーマとした大学 講義を実施してきた理由は, 2016 年の公職選挙法 改正に伴い選挙権年齢が 20 歳から 18 歳に引き下 
げられたことにより, 新たに有権者となった高校 3 年生と大学 $1 \cdot 2$ 年生に対する政治的リテラシー を養成するための教育が必要になってきたからで ある。この政治的リテラシーとは政治的判断能力 や批判能力のことであり, 政治的リテラシー重視 の考え方は, 1998 年に発表された「クリック・レ ポート (DFEE, 1998)」の影響が大きいとされて いる(小玉, 2016)。そして, このレポートには政 治的リテラシーを有する市民を育成するため, 市 民としての資質・能力を育成するための教育，す なわち, シティズンシップ教育の重要性が述べら れている。さらに, この教育手法には, 国民の間 で政治的な対立意見のある「論争的問題」を取り 扱うことが有効とされており, 本研究のテーマと なっている「原発再稼働の賛否」は, まさにこの 論争的問題のひとつである。

原発再稼働の賛否意見については, 新聞各社に よる世論調査でも明らかなように, 反対意見が賛 成意見よりも多い傾向にある。これらの調査は, 国 民がもつ現時点での意見を把握するには有効であ ろう。しかし,これらの意見が必ずしもエネルギー に関する諸問題を理解した上で導かれた最終的な 意見であるとは限らない。つまり，「原発は怖いか ら反対」「再生可能エネルギーはクリーンだから賛 成」といった大多数が抱いているであろうイメージ を，そのまま自分の意見としている可能性がある。 そこで著者らは, 京都光華女子大学 (以下, 本学) の一般教養科目「シチズンシップ」において, 論 争的問題として原発再稼働の賛否を取り上げ, 講 義毎に多角的な観点からエネルギー問題に関する 情報を提供することで, 受講者の意志決定プロセ スを検討してきた（ただし,ここでは本学が女子大 学であることから, 調查対象の年齢層と性別が限 定されていることに留意する必要がある)。その結 果, 講義前は, 「原発は怖い」「安全面で信用でき ない」といったイメージ先行の理由により, 反対意 見が賛成意見を大きく上回っていたが（反対 $62 \%$, 賛成 $38 \%: n=368)$, 講義を重ねる度に, 賛否割合 の差が縮まり,すべての講義を終えた段階では, 賛 成と反対の意見がほぼ半数（反対 $49 \%$, 賛成 $51 \%$ : $\mathrm{n}=326)$ となる結果を得た（ $\mathrm{p}<0.001 ）$ 。しかし, 賛 成に転じた多くの理由は，「原発に頼るしか方法が ない」といった必ずしも積極的な賛成意見ではな いことも同時に明らかにした（高野ら，2018a）。

\section{2 本研究の目的}

著者らは, 過去 2 年間における原発再稼働賛否 の調査において，いずれも講義を重ねるごとに賛 否割合の差が縮まる傾向にあることを明らかにし ている(高野ら, 2017・2018a)。しかし, これら の結果は, 複数同時開講されているクラスをまと めて論じたもの, つまり, 本学学生の全体傾向を 示したものとなっている。各クラスにおける賛否 変化について, 実際には, 講義毎に大きく摇らぐ クラスもあれば, 大きな変化がないクラスもあり, それぞれに特有の傾向がある。2017年度に調査し たこれらの傾向は速報として, 日本環境学会第 44 回研究発表会にて報告している（高野ら, 2018b）。

シティズンシップ教育において論争的問題を取 り扱う場合, 受講者に公平・中立な立場で情報を 提供することが重要であることは言うまでもな い。そして, より丁寧な教育のため, 複数のクラ スを同時開講し，できる限り少人数クラスで実施 することを心がけている。従って, 同じ教材を使っ て同じ情報を提供するものの，それらを教授する 教員は異なる。さらに, 各クラスは学科ごとに大 別しているため, 学科による専門性の違いの他, 入学試験等の難易度も異なることから, 受講者の 学習状況にも違いがあるかもしれない。もし，原 発再稼働の賛否に対する教員の意識や, 受講者の 専門性，あるいは学習状況が賛否意見に影響する ようであれば, これらの影響因子を考慮したより 最適なシティズンシップ教育の教授法を検討する 必要がある。

そこで本研究では, 2018 年度に開講した科目 「シチズンシップ」で得られた結果を元に, 原発再 稼働賛否意見の変動に対する受講者の専門性や大 学入学時の学習状況, 及び講義担当教員の意識の 影響について明らかにすることとした。

\section{3. 研究方法}

\section{1 科目「シチズンシップ」について}

本科目は 1 年次の全ての学生が受講する（一部 の学部のみ 3 年次受講) 必修科目となっている (乾 ら, 2017)。クラス構成は表 1 に示すように, I 〜 VIIIの 8 クラスを $A \sim E$ の 5 名の教員が担当するこ 
表 1 科目「シチズンシップ」のクラス構成

\begin{tabular}{|c|c|c|c|c|c|}
\hline クラス & 担当教員 & 受講者の所属学科 & 平均点順位 & 受講者数 & 学年 \\
\hline I & $A$ & \multirow{2}{*}{$\begin{array}{c}\text { S（文系 > 理系） } \\
\mathrm{T} （ \text { 文系 < 理系 }) \\
\mathrm{U} \text { (文系) }\end{array}$} & \multirow{2}{*}{$\begin{array}{l}3 \\
6 \\
7\end{array}$} & \multirow{2}{*}{$\begin{array}{l}41 \\
31 \\
14\end{array}$} & \multirow[b]{2}{*}{1} \\
\hline II & $B$ & & & & \\
\hline III & $A$ & \multirow{2}{*}{$\begin{array}{c}\mathrm{V} \quad(\text { 文 }<<\text { 理系 }) \\
\mathrm{W}(\text { 文系 }<<\text { 理系 })\end{array}$} & \multirow{2}{*}{$\begin{array}{l}2 \\
4\end{array}$} & \multirow{2}{*}{$\begin{array}{l}75 \\
36\end{array}$} & \multirow{2}{*}{1} \\
\hline IV & $C$ & & & & \\
\hline V & $A$ & \multirow{3}{*}{$\begin{array}{c}X \quad \text { (文系 }<<\text { 理系 }) \\
Y \quad(\text { 文系 }>>\text { 理系 })\end{array}$} & \multirow{3}{*}{$\begin{array}{l}1 \\
5\end{array}$} & \multirow{3}{*}{$\begin{array}{l}83 \\
75\end{array}$} & \multirow{3}{*}{1} \\
\hline $\mathrm{VI}$ & $D$ & & & & \\
\hline VII & $E$ & & & & \\
\hline VIII & $D$ & Z (文系) & - & 72 & 3 \\
\hline
\end{tabular}

学際領域の学科については, 文系・理系の学びの大きさを不等号で表現している。平均点順位は, 各学科に㧍け るプレースメントテスト (英語) の平均点の順位である。

とになっており，学科間における受講者どうしの 交流を目的として, できる限り異なる学科の学生 が混ざり合うように編成されている。例えば，担 当教員 $A$ が担当する I クラスは, $\mathrm{S}$ 学科, $\mathrm{T}$ 学科, $\mathrm{U}$ 学科のそれぞれ半数の学生が受講していること になる。学科の専門性については, 学際領域の学 科が多数あるため, 理系分野と文系分野の学びの 比率を不等号で表した。また, これらの学科に所 属する学生の学習状況については, 入学直後に実 施するプレースメントテスト（英語）の結果を採 用した。同表中の平均点順位は, 各学科の英語の 平均点の順位である。入学前に文系・理系ともに 必修科目として十分に学習し, その学習状況が点 数の違いにもっとも反映されやすいと考えられる 英語を指標とした。横山（2016）でも, 初年次学 生の学力を測る指標として英語力を持いている。 (ただし Z 学科については学年が異なり, かつ, テ スト問題も異なるため, 集計から外した。)

なお, 本科目で提供する論争的問題は, 「原発再 稼働の是非」の他, 「消費税増税の是非」「憲法改 正の是非」「地元自治会への参加の是非」の 4 つの テーマを設定しており, その内, 「原発再稼働の是 非」については, 全 15 回の講義の内, 3 回を割り 当てた。次に, 講義各回で受講者に提示した講義 内容について述べる。

\section{2 講義内容}

\subsection{1 第 1 講: エネルギー問題に関する基本事項}

最初に, 各種電気エネルギー（原子力・灭力
風力 · 太陽光 ·地熱 - 水力・バイオマス）の発電 方法について簡単に説明した後, 東日本大震災前 後における電力構成の変化（震災前には原発が 3 割程度を占めていたが, 現在はそのほとんどを火 力で補っていること（資源エネルギー庁，2018）） を提示した。続いて, 現代社会において電気が如 何にインフラとして大切か（鉄道等の公共交通機 関の他, 水道やガスの供給, 通信等の多くで電気 が必要となることや, 電力消費量がここ 20 年で 3 〜4 割増大していること（澤, 2012））を説明した。 そして，日本における震災前のエネルギー基本計 画が3つの E (Energy Security:エネルギー安全 保障, Economy: 経済性, Environment: 環境性) を基軸としたものであったのに対し, 震災後には, この $3 \mathrm{E} に \mathrm{~S}$ (Safety: 安全性) の概念が追加され たこと等を説明した。

\section{2 .2 第 2 講 : 再生可能エネルギーと原発のデメ リットを中心に}

まず，各種エネルギーを原子力，火力，再生可 能エネルギーの 3 種類に大別し, それぞれのメ リット・デメリットを受講者個人で考えさせた。そ の後, ペアワークとして受講者どうしで意見交換 した。そして,メリット・デメリットの事例（高 野, 2016）を教員から紹介した。次に, 再生可能 エネルギー固定買取制度を紹介し, 買取価格や期 間の他, 電気利用者の全てから賦課金が徴収され ていることを述べた。さらに, 太陽光発電に伴う 日照権の問題, 風力発電に伴う低周波騒音問題等 も紹介し, 再生可能エネルギーのデメリットを中 
心に説明した。一方，原発については，再生可能 エネルギーの発電コストが原発や火力発電に比べ て高いとされるものの（資源エネルギー庁, 2016a), 原発には巨額のバックエンドコスト ${ }^{2)}$ が 発生している（青木，2016）ことなどを紹介した。 そして, 事故が起きた時の被害の甚大さは他の工 ネルギー源とは比較にならないことの他, 日本の 年間放射線被曝量の許容值 $(20 \mathrm{mSv})$ が専門家の 立場から放射線防護に関する锥告を行う ICRP(国 際放射線防護委員会)の定めた許容值 $(1 \mathrm{mSv})$ よ りも高い等, 原発のデメリットを中心に説明した。

\subsection{3 第 3 講: 再生可能エネルギーの将来性を中 心に}

ここでは, 最初に現政府が発表しているエネル ギーミックスの概念を説明した後, 2030 年の電源 構成を紹介した（資源エネルギー庁，2018b）。続 いて, 再生可能エネルギーの発電コストが今後減 少する見达みのあることや（資源エネルギー庁, 2016b)，パラグアイでは既に再生可能エネルギー 割合が150\%に到達しており，80\%を超える国も 多く存在することを述べた。そして，日本には森 林や火山が多く, 島国でもあるため, バイオマス 発電, 地熱発電, 波力発電等のポテンシャルが極 めて高いこと等も紹介した（和田，2016）。

\section{3 受講者と教員への調査内容 \\ 3.3.1 受講者への調査内容}

本研究では, 講義各回の前後に「原発再稼働に 賛成ですか，反対ですか？」という質問を受講者 に投げかけた。次に,「賛成」と答えた受講者に は, その理由を，11効率がよく電気料金が安いか ら, (2)福島第一原発事故後の新安全基準で安心だ と思うから，(3)安全性の問題はあるが，原発に頼 る他方法がないから, (4)地球温暖化防止のために は $\mathrm{CO}_{2}$ 排出量の少ない原発がよいと思うから, (5) エネルギー自給率が向上し, 安定供給が望めると 思うから, (6)その他, の6つの中から一つ選択さ せた。一方,「反対」と答えた受講者には, その理 由を，(1)原発は怖いというイメージがどうしても 先行するから，(2)とにかく安全面で信用できない から, (3)太陽光などの再生可能エネルギーでもっ と賄えると思うから，(4)事故後の処理費を考える と安くないと思うから, (5)核燃料廃棄物の問題が
解決できないと思うから, (6)その他, の6つの中 から一つ選択させた。

このような講義中の調査については, クリッ カー (KEEPAD JAPAN 製)を用いた。受講者一 人ずつに数字の並んだリモコンを配布し，教員の 質問に対してボタンを押すことで回答できる。集 計結果は瞬時にグラフ化されるため, その場でク ラス全体の意見傾向を共有することができる。た だし，本研究では学科別または担当教員別に集計 する必要があるため, ここでは質問紙でも同内容 を調査した。なお, 賛否割合の有意差については, $\chi^{2}$ 法およびstudent の $\mathrm{t}$ 検定を用い, 回答数が少 ないものについてはフィッシャーの直接確率検定 を採用した。また，賛成・反対意見の変化の度合 いを標準偏差 $(\mathrm{S})$ で表し, 3 講分 $\times 2$ 回（最初， 最後）の計 6 回の賛成割合の変化の度合いを不偏 標準偏差で計算した。これらの評価には Excel

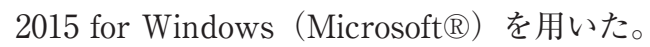

\subsection{2 教員への調査内容}

各クラスを担当した 5 名の教員 $A \sim E$ に対して, 全講義終了後に以下の 3 つの項目について調査し た。質問 1 「原発再稼働に賛成ですか, 反対です か?」に対して，(1)賛成，(2)どちらかと言えば賛 成，(3)どちらとも言えない，(4)どちらかと言えば 反対，(5)反対の 5 つから選択した。質問 2 「講義 中は，スライドや配布資料に記載のない内容も紹 介していますか？」に対して，11紹介している， (2)ときどき紹介している, (3)ほんど紹介してい ない, (4)紹介していない, の4つから選択した。 質問 3 「講義内容を説明するときは，どのように 説明していますか？」に対して，11淡々と説明す るスタイル，(2)どちらかと言うと淡々と説明する スタイル，(3淡々と説明する場合と，力を込めて 説明する場合が半々ぐらい, (4)どちらかと言うと 力を込めて説明するスタイル，(5)をを込めて説明 するスタイル，の 5 つから選択した。表 2 にこれ らの調査結果を示す。質問 1 に対して, $A, B, C$ の 3 名の教員が「(4)どちらかと言えば反対」と回 答した。また，教員 $D$ は「(2)どちらかと言えば賛 成」と回答し, 教員 $E$ は「(5)反対」という明確な 意見を持っていた。次に, 質問 2 に対して, $A, C$, $E$ の 3 名の教員が「(2)ときどき紹介している」と 回答し, 教員 $B$ が「(1)紹介している」, 教員 $D$ は 
表 2 教員の原発再稼働に関する意見や講義スタイルに関する自己評価

\begin{tabular}{|c|c|c|c|c|c|}
\hline 教員 & A & $\mathrm{B}$ & $\mathrm{C}$ & $\mathrm{D}$ & $\mathrm{E}$ \\
\hline \multicolumn{6}{|l|}{ 質問 1 : 原発再稼働に賛成ですか, 反対ですか？ } \\
\hline \multicolumn{6}{|l|}{ (1) 賛成 } \\
\hline (2) どちらかと言えば賛成 & & & & $\bigcirc$ & \\
\hline \multicolumn{6}{|l|}{ (3) どちらとも言えない } \\
\hline (4) どちらかと言えば反対 & $\bigcirc$ & $\bigcirc$ & $\bigcirc$ & & \\
\hline (5) 反対 & & & & & ○ \\
\hline \multicolumn{6}{|l|}{$\begin{array}{l}\text { 質問 2：講義中は，スライドや配布資料に記載のない内容も紹介し } \\
\text { ていますか？ }\end{array}$} \\
\hline (1) 紹介している & & $\mathrm{O}$ & & & \\
\hline (2) ときどき紹介している & $\bigcirc$ & & O & & O \\
\hline (3) ほとんど紹介していない & & & & O & \\
\hline \multicolumn{6}{|l|}{ (4) 紹介していない } \\
\hline \multicolumn{6}{|l|}{ 質問 3:講義内容を説明するときは, どのように説明していますか？ } \\
\hline \multicolumn{6}{|l|}{ (1) 淡々と説明するスタイル } \\
\hline (2) どちらかと言うと淡々と説明するスタイル & & & & $\bigcirc$ & \\
\hline (3) 淡々と説明する場合と, 力を込めて説明する場合が半々ぐらい & & $\bigcirc$ & $\bigcirc$ & & $\mathrm{O}$ \\
\hline (4) どちらかと言うと力を込めて説明するスタイル & $\bigcirc$ & & & & \\
\hline (5) 力を込めて説明するスタイル & & & & & \\
\hline
\end{tabular}

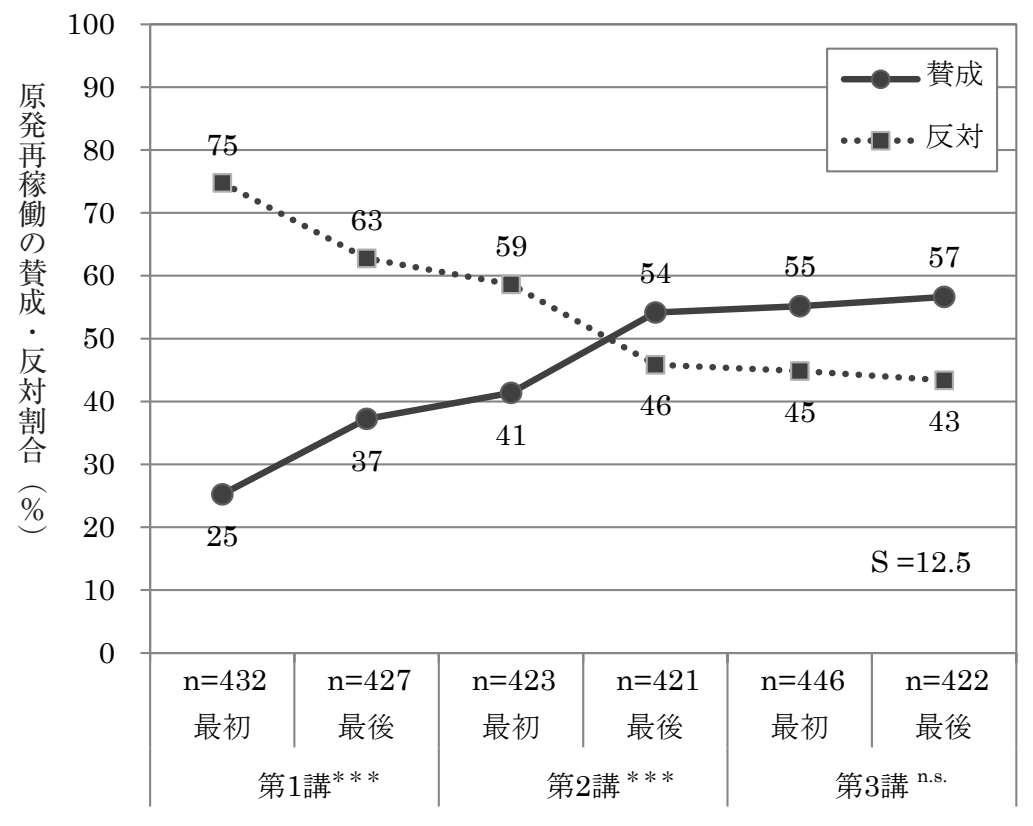

第 $1 \rightarrow 3$ 講***

n.s. : 非有意, ${ }^{\dagger}: \mathrm{p}<0.1, *: \mathrm{p}<0.05, * *: \mathrm{p}<0.01, * * *: \mathrm{p}<0.001$

図 1 全受講者の講義毎における原発再稼働の賛成・ 反対割合の推移 
「(3)とんど紹介していない」と回答した。そし て, 質問 3 に対して, $B, C, E$ の 3 名の教員が 「(3)淡々と説明する場合と, 力を込めて説明する場 合が半分ずつぐらい」と回答し, 教員 $A$ が「(4)ど ちらかと言うと力を込めて説明するスタイル」と 回答した。教員 $D$ は「(2)どちらかと言うと坦々と 説明するスタイル」と回答した。

\section{4. 結果一原発再稼働賛否の意見变動一}

\section{1 受講者全体の意見変動}

図 1 に, 全受講者の第 1 講 3 講の講義におけ る原発再稼働の賛成・反対割合の推移を示す。第 1 講から第 3 講にかけて, 賛成割合が単調増加し, 反対割合が単調減少した（第 1 講の最初：賛成 $25 \%$ ・反対 $75 \%(\mathrm{n}=432)$, 第 3 講の最後 : 賛成 $57 \%$ ・反対 $43 \% （ \mathrm{n}=422 ）$ 。 $\chi^{2}$ 乗検定の結果，第 1 講および第 2 講において, 講義前と講義後で賛 成・反対割合の比率に有意差がみられ, 第 1 講の 最初と第 3 講の最後でも有意差が見られた。

表 3 は, 第 1 講から第 3 講の講義前と講義後で, （a）反対から賛成，（b）賛成から反対に意見変容 した受講者に関して, 変容理由の選択数を示す。 （a）においては，反対理由「(2)とにかく安全面で 信用できないから」から賛成理由「(3)安全性の問 題はあるが，原発に頼る他方法がないから」を選 択した受講者 72 名がもっと高い割合で, 全体 176 名の約 40.9\%であった。（b）においては，賛成理 由「(3)安全性の問題はあるが, 原発に頼る他方法 がないから」から反対理由「(3)太陽光などの再生 可能エネルギーでもっと賄えると思うから」を選 択した受講者 20 名がもっと高い割合で, 全体 61 名の約 $32.8 \%$ であった。

\section{2 受講者の専門性と学習状況の違いによる影響}

図 2.1 および図 2.2 に, 図 1 の全学科分のグラフ を 8 つの学科に分けた, 第 1 講から第 3 講の賛成・ 反対割合の変容を示す。 8 つ全ての学科で, 第 1 講の講義前は賛成より反対意見の割合のほうが高 かった。そして, 講義回を通じて反対より賛成の 割合が高くなったのは 6 学科であった。そのタイ ミングは, 第 1 回の講義後は $\mathrm{W}$ 学科, 第 2 回の講 義前は $\mathrm{Z}$ 学科, 第 2 回の講義後が $\mathrm{T}, \mathrm{V}$ 学科, 第 3 回の講義前が $S, U$ 学科であった。第 3 講の講
表 3 各理由で賛成・反対へ意見変容した人数 （a）「反対」から「賛成」へ変容の理由

\begin{tabular}{|c|c|c|c|c|c|c|c|}
\hline & \multicolumn{6}{|c|}{ 賛成理由 } & \\
\hline 反対理由 & (1) & (2) & (3) & (4) & (5) & (6) & 総計 \\
\hline (1) & 4 & 2 & 13 & 6 & 3 & & 28 \\
\hline (2) & 6 & 2 & 72 & 2 & 11 & 2 & 95 \\
\hline (3) & 4 & & 16 & 2 & 2 & & 24 \\
\hline (4) & 2 & & 2 & 1 & 1 & 1 & 7 \\
\hline (5) & & & 15 & 3 & 2 & & 20 \\
\hline (6) & & & 1 & & & 1 & 2 \\
\hline 総計 & 16 & 4 & 119 & 14 & 19 & 4 & 176 \\
\hline
\end{tabular}

反対理由: (1)原発は怖いというイメージがどうしても 先行するから，(2)とにかく安全面で信用できないか ら, (3)太陽光などの再生可能エネルギーでもっと賄え ると思うから, (4)事故後の処理費を考えると安くない と思うから, (5)核燃料廃棄物の問題が解決できないと 思うから, (6)その他

（b）「賛成」から「反対」へ変容の理由

\begin{tabular}{|c|r|r|r|r|r|r|r|}
\hline & \multicolumn{7}{|c|}{ 反対理由 } \\
\hline 賛成理由 & (1) & (2) & (3) & 4 & (5) & 6 & 総計 \\
\hline (1) & 2 & 3 & & 1 & & & 6 \\
\hline (2) & & 2 & & & & & 2 \\
\hline (3) & & 11 & 20 & 3 & 4 & 7 & 45 \\
\hline (4) & & 1 & 1 & 1 & 1 & & 4 \\
\hline (5) & & 2 & & 2 & & & 4 \\
\hline (6) & & & & & & & \\
\hline 総計 & 2 & 19 & 21 & 7 & 5 & 7 & 61 \\
\hline
\end{tabular}

賛成理由：(1)効率がよく電気料金が安いから，(2)福島 第一原発事故後の新安全基準で安心だと思うから, (3) 安全性の問題はあるが, 原発に頼る他方法がないか ら, (4)地球温暖化防止のためには $\mathrm{CO}_{2}$ 排出量の少な い原発がよいと思うから, (5)エネルギー自給率が向上 し, 安定供給が望めると思うから, (6)その他

義後でも賛成より反対意見の割合が高かったの は, $\mathrm{X}$ 学科, $\mathrm{Y}$ 学科の 2 学科のみであった。一方, 3 回分の講義を通じた賛成・反対意見の変化の度 合い（標準偏差：S）は学科により異なり, 特に $\mathrm{W}, \mathrm{X}$ 学科は小さかった $(\mathrm{W}$ 学科 $\mathrm{S}=7.5, \mathrm{X}$ 学科 $\mathrm{S}=7.3)$ 。そして, この 2 学科については, 表 1 で 示したように理系的な学びの割合が大きい学科で あった。また, 標準偏差の最も大きいU 学科につ 


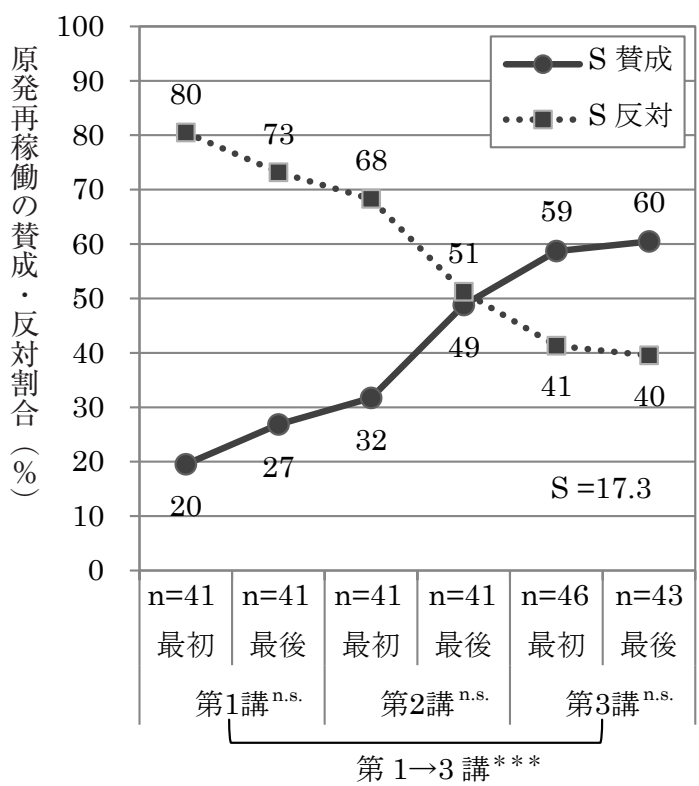

(a) $\mathrm{S}$ 学科

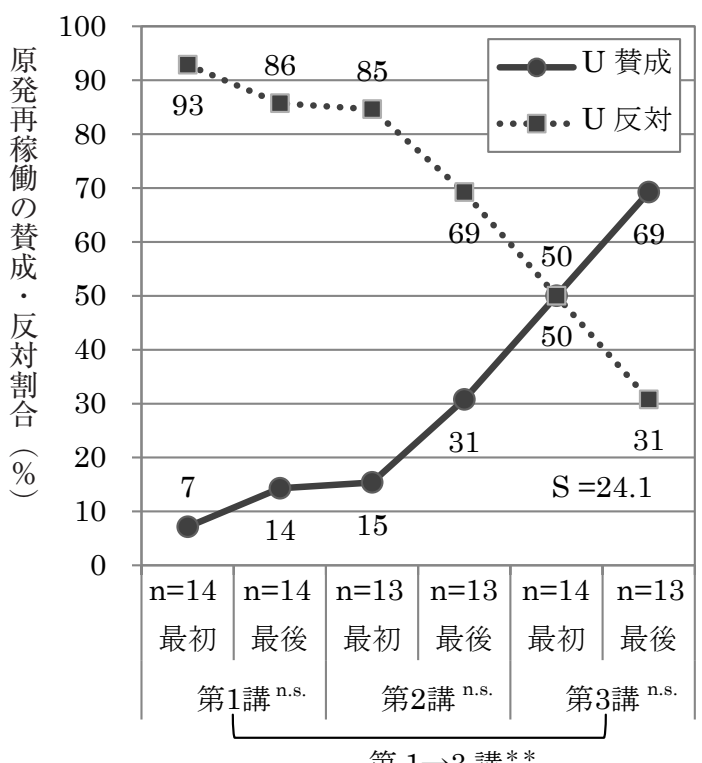

第 $1 \rightarrow 3$ 講**

(c) U 学科

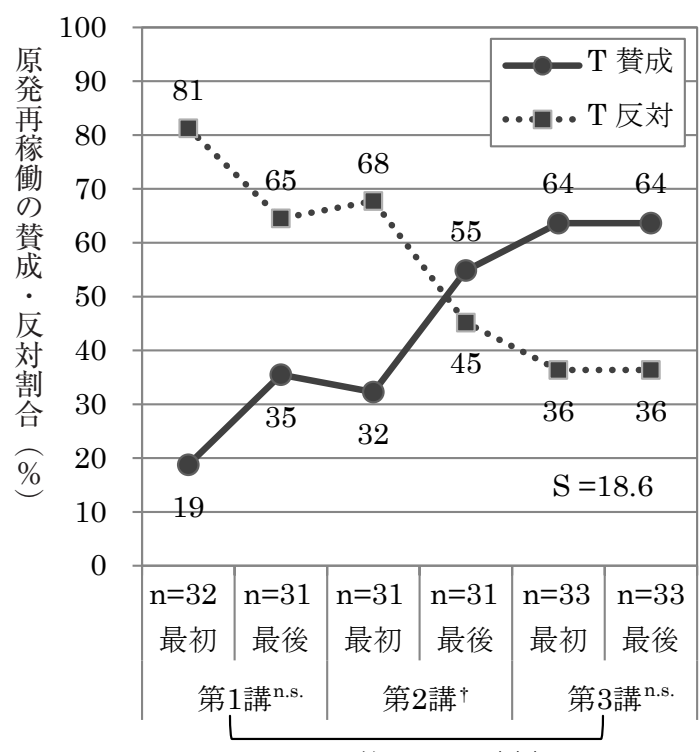

第 $1 \rightarrow 3$ 講***

(b) $\mathrm{T}$ 学科

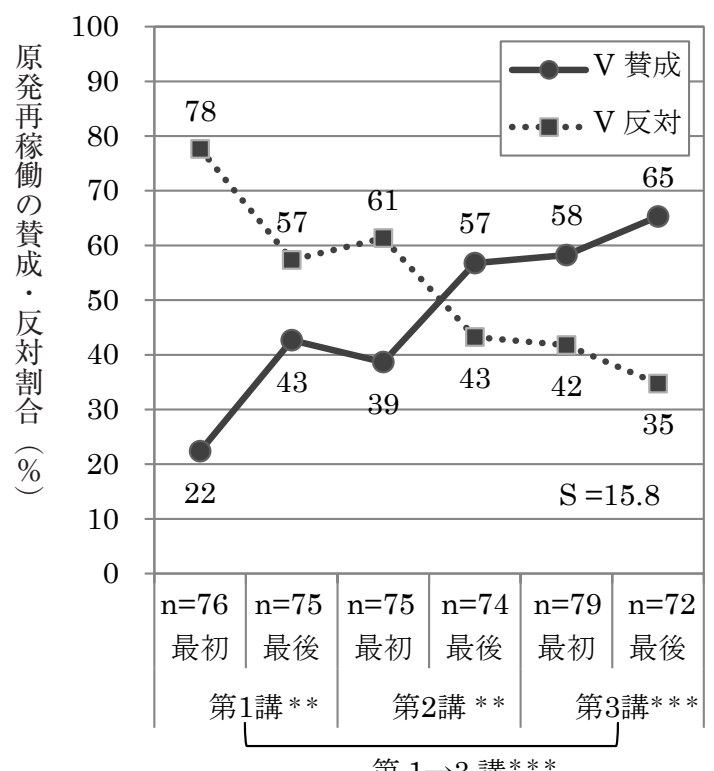

第 $1 \rightarrow 3$ 講***

(d) $\mathrm{V}$ 学科

n.s. : 非有意, ${ }^{\dagger}: \mathrm{p}<0.1, *: \mathrm{p}<0.05, * *: \mathrm{p}<0.01, * * *: \mathrm{p}<0.001$

図 $2.1 \mathrm{~S} \sim \mathrm{V}$ 学科の講義毎における原発再稼働の賛成・反対割合の推移

いては文系的な学びを軸とする学科である。

次に, 各学科の大学入学時のプレースメントテ スト (英語) の結果と標準偏差の関係について述 べる。調査対象とした 7 学科の中では, 標準偏差 が最も小さい X 学科 $(\mathrm{S}=7.3)$ のテストの平均点
は最も高く，逆に標準偏差が最も大きいU 学科 （S=24.1）については，テストの平均点が最も低 かった。全体として，テストの平均点が高い学科 ほど標準偏差が小さい傾向にあり，これらは負の 相関を示した $(r=-0.438)$ 。 


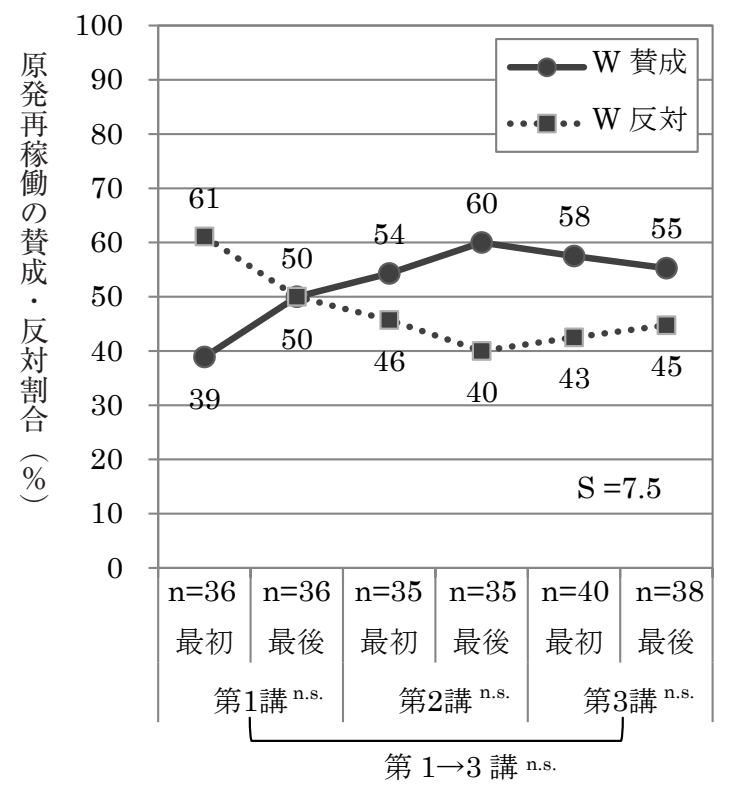

(a) $\mathrm{W}$ 学科

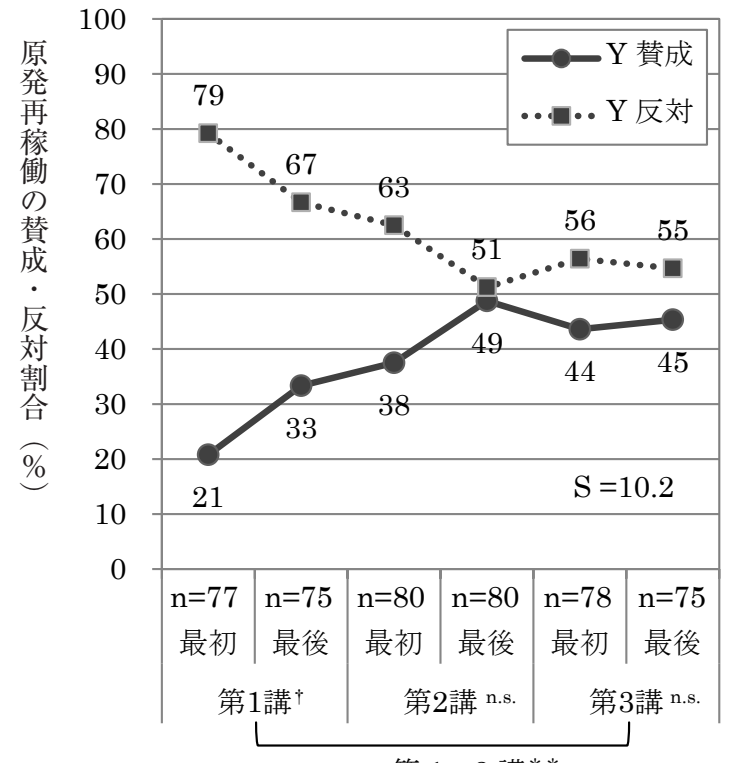

第 $1 \rightarrow 3$ 講**

(c) $\mathrm{Y}$ 学科

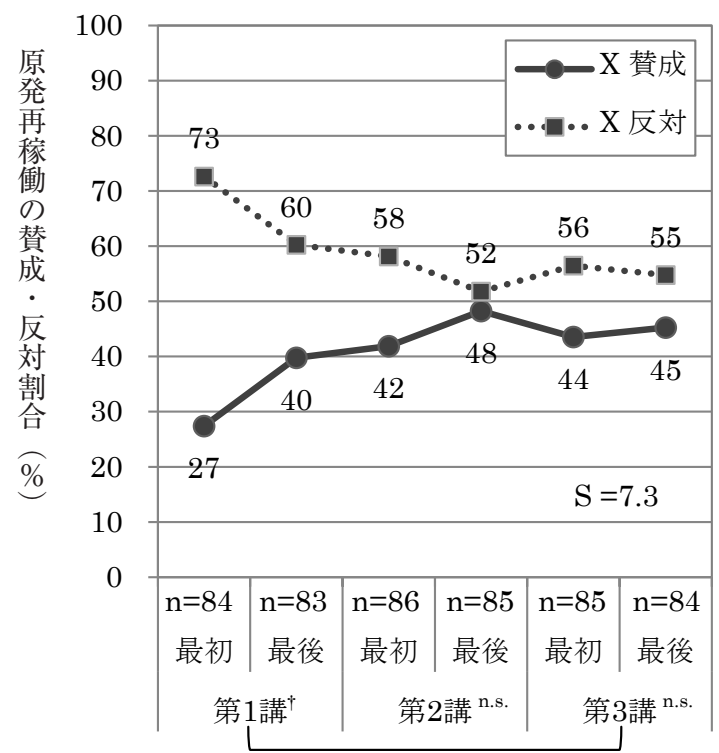

第 $1 \rightarrow 3$ 講*

(b) $\mathrm{X}$ 学科

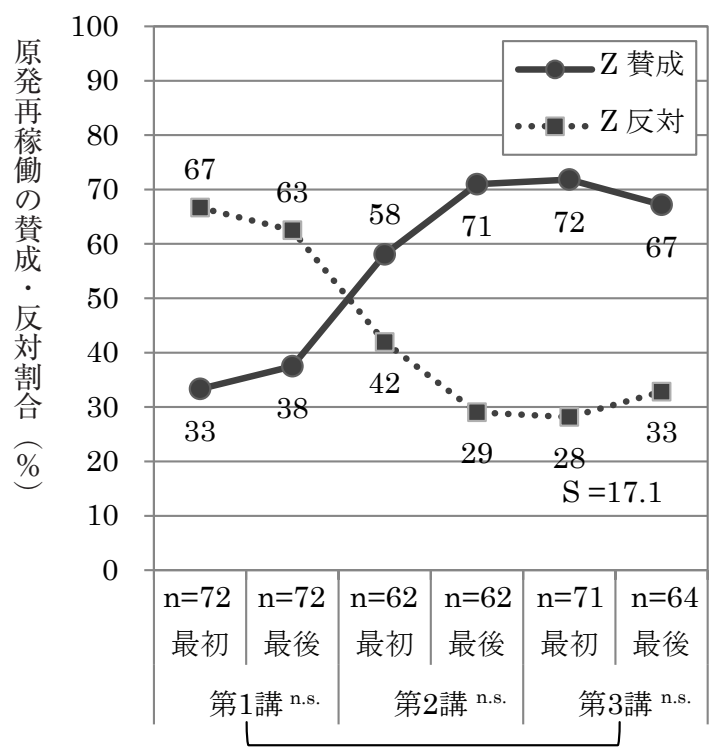

第 $1 \rightarrow 3$ 講***

(d) $\mathrm{Z}$ 学科

n.s. : 非有意, ${ }^{\dagger}: \mathrm{p}<0.1, *: \mathrm{p}<0.05, * * \mathrm{p}<0.01, * * * \mathrm{p}<0.001$

図 $2.2 \mathrm{~W} \sim \mathrm{Z}$ 学科の講義毎における原発再稼働の賛成・ 反対割合の推移

\section{3 教員の違いによる影響}

図 3 に, 図 1 の全学科分の賛否動向を講義担当 した教員 5 名のクラスに分けた，第 1 講から第 3 講の賛成・反対割合の変容を示す。教員 $A, B, C$, $D$ のつのクラスでは, 3 回分の講義を通じて, 反
対割合より賛成割合が有意に高くなる意見変容が みられた。最も大きな変容がみられたのは教員 $\mathrm{A}$ のクラスであった $(\mathrm{S}=16.6)$ 。一方，教員 $E$ のク ラスのみ, 3 回分の講義を通じて, 反対割合がさ らに高く，賛成割合がさらに低くなり，賛否割合 


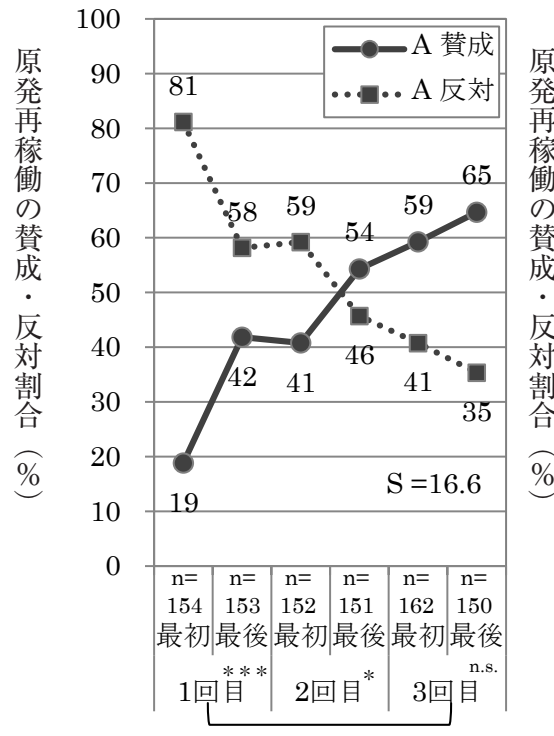

第 $1 \rightarrow 3$ 講***

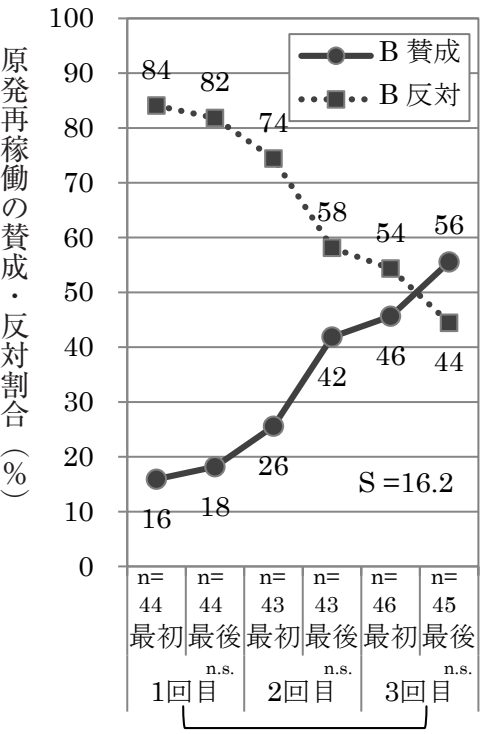

第 $1 \rightarrow 3$ 講***

(a) 教員 $A$ クラス

(b) 教員 $B$ クラス

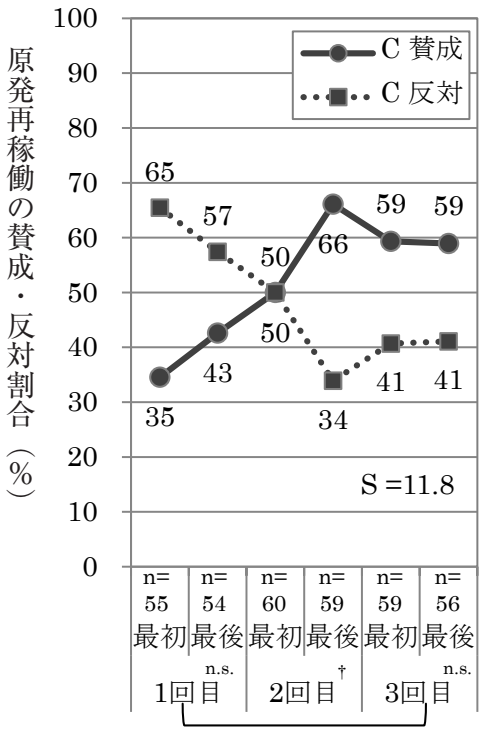

第 $1 \rightarrow 3$ 講*

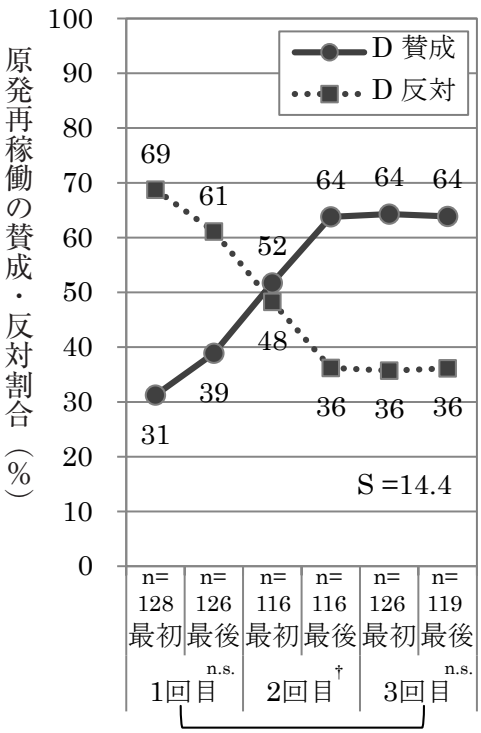

第 $1 \rightarrow 3$ 講***

(c) 教員 $C$ クラス

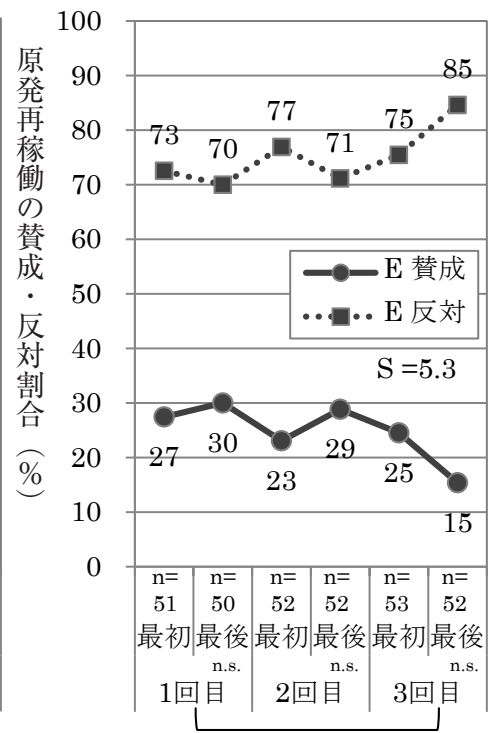

第 $1 \rightarrow 3$ 講 n.s.

(e) 教員 $E$ クラス

n.s. : 非有意, ${ }^{\dagger}: \mathrm{p}<0.1, *: \mathrm{p}<0.05, * * \mathrm{p}<0.01, * * * \mathrm{p}<0.001$

図 3 教員 $A \sim E$ の各クラス講義毎における原発再稼働の賛成・反対割合の推移

が入れ替わることはなかった $(\mathrm{S}=5.3)$ 。

\section{5. 考察一受講者の原発再稼働賛否意見に及ぼ す影響因子一}

\section{1 賛否意見の変容}

全体的な賛否意見の態度変容については, 反対
から賛成に転じる傾向があり，賛成に転じた理由 として「安全性に問題はあるが，原発に頼る他方 法がないから」であった。これについては，福島 第一原発事故の悲惨な状況を多くの報道で予め 知っていたために，原発に対してマイナスイメー ジからスタートしていたものが，原発が再生可能 
エネルギーに比べて発電効率が極めて高いこと や，一般に環境に良いとされる再生可能エネル ギーでさえ，その普及のためにはいくつかの課題 があるという，必ずしも十分に報道されていない 部分について授業を通じて改めて学んだため, や むを得ず賛成に転じた可能性がある。しかし，例 えば態度変容がある方が講義として望ましい等, 態度変容の有無に優劣はない。重要なことは, 3 回分の講義で紹介される科学的な根拠を理解し, 自分の価值判断に基づいて重要度を評価した上 で，賛否のいずれかの意見を形成するプロセスで ある。小島（2017）らは，遺伝子組み換えに関す る高校での講義の一環で, 賛成意見, 反対意見に ついて科学的な視点で吟味する学習内容を取り入 れ，日常生活と関連づけて遺伝子組み換え技術の 利用について検討する時間を十分にとる必要性を 考察している。また竹内（1994）は, 事実認識と 価值認識の統一的な形成を行い, 学習者の行動・ 態度を変容させていくことを目的とする「理論・ 価值追求型」の講義の重要性を指摘している。こ のように賛否の意見形成や態度変容の科学的根拠 を論理的に自分の頭で判断するリテラシーの修得 が本講義の目的であり, 講義で学んだ事実を元に 考え, 自分で考えたことで意見が変容したという 結果から, 本講義の目的は達成されていると言え る。

\section{2 受講者の専門性や学習状況と意見変容の相関}

4.2 節で述べたように, 受講者の専門性によって 意見変容に違いがみられた。岡本（2016）は，入 学直後の国立大学 1 年生, 理系・文系の各 2 学部 に所属する学生を対象に, 科学の本質に関する 6 テーマの理解度を調査した。その結果, 学生の所 属学部や選択科目により理解度の異なるテーマが あり，特に，科学に対する社会的および文化的影 響や, 科学研究における想像力・創造力の役割で は，学部間で有意差があることを報告している。 従って, 本研究のテーマのように, エネルギー問 題という理系的な観点も重要となる分野において は, 理系を中心に学ぶ（理系的に思考する傾向の ある）学生の方が自分の意見を導くための科学的 根拠を予め持ち合わせていた可能性がある。

また, 受講者の入学前における英語の学習状況
によって標準偏差に変化がみられ，意見変容との 間に負の相関が得られた。科目「シチズンシップ」 では, 全 3 講の講義の内, 各種エネルギーのメリッ トとデメリットに関する情報を提供し, 受講者に 「ゆさぶり」をかけて,これまで抱いていたであろ う紋切り型の考えを改めるように講義設計してい る（乾ら，2017）。このため, 一つの見方として， 学習経験が少ないであろう（ここでは英語テスト の成績が低い）受講者ほど，意見が講義毎に激し く摇れる，換言すると，このような受講者は与え られた情報に左右されやすい可能性がある。一方, 学習経験が豊富な受講者の意見は, 与えられた情 報よりも予め自分でもっていた考えを支持する何 らかの根拠があると捉えることができよう。著者 は, 以前, 京都に立地する受験難易度の極めて高 い国立大学で 1 回のみの講義（今回の 3 回分の講 義を 1 回に集約) ではあるが, 本研究と同様に講 義前後における賛否動向を調査した $(n=27)$ 。そ の結果, 講義前が賛成 $57 \%$, 反対 $43 \%$ で, 最初か ら賛成意見が反対意見よりも多く（国民の世論調 査と逆の傾向), 講義後に賛成が $66 \%$, 反対が $34 \%$ であり，大きな変化は見られなかった。

ここでは, 学科の専門性が学際領域であるため, 文系・理系を明確にすることが難しい点や, 学習 状況を英語のみで考察している点で不確定性があ るものの，このような賛否意見に対する影響が見 られるのであれば，その影響度合いをさらに明確 にした上で, 多様な受講者に対応できる講義内容 の検討が今後必要になるであろう。

\section{3 教員個人の考えの影響}

図 3 (e) に示したように, 教員 $E$ のクラスにつ いては, 唯一賛成と反対の割合が交差せず $(\mathrm{S}=5.3)$ ，常に反対割合が高い状態を維持してい た。このクラスを担当した教員 $E$ の個人的な考え としては, 表 2 に示したように，原発再稼働につ いては明確な反対意見をもっていた。これらの結 果から, 受講者が教員 $E$ の考えに影響を受けた可 能性は否定できない。また, 図 3 (a) の教員 $A$ の クラスは賛否の変異が最も大きいクラスであった $(\mathrm{S}=16.6)$ 。教員 $A$ は表 2 に示したように, 講義内 容は力を込めて説明する傾向がある。このため, 受講者は教員の説明内容に大きく左右された可能 
性がある。さらに, 教員 $D$ は 5 名の教員の中で唯 一人，原発再稼働に賛成意見を持っている。この 教員のクラスの賛否の変異は第 2 回の講義の後半 から第 3 回の最後にかけて, 原発再稼働に賛成す る受講者の割合が比較的高い状況を維持している ことから, 教員 $D$ の考えが受講者に影響を与えた 可能性もあるだろう。

このような受講者の意見に対する教員の影響に ついて, 速水（2016）は高等学校の家庭科教育に おいて, 20 年の教育経験のある専任教員と, 週 3 日勤務している非常勤講師のクラスにおける生徒 の学習内容の理解や興味・関心について調査した。 その結果, 専任教員のクラスの生徒に特定分野へ の興味・関心が高まることが明らかになったこと を報告している。また, 渡部（2016）は社会科を 専門教科としてきた小中学校のベテラン教師と, 社会科の授業研究を専門とする教育学者が, 小学 校 4 年生の社会科の授業映像を分析・評価して, 両者の分析の視点や姿勢の違いを検証した。その 比較の結果, ベテラン教師のコメントは, 教師や 子どもたちの具体的な様子を取り上げる傾向があ り，授業のねらいについて触れることが少なかっ た。一方, 教育学者のコメントの多くは, 教師の 教えている内容や授業全体の構造，そして授業の ねらいに関心があり，そのねらいで社会科授業を することの意味を問うものであった。これらの違 いの要因として, ベテラン教師および教育学者が 置かれてきた環境, そして大学時代に専門として きた学問体系などが影響していると考察してい る。図 3, 表 2 の教員 $A \sim E$ の 5 名間で, 専門分 野, 大学教員に至った経緯は大きく異なることか ら, こうした要因も加味しながら, 学生の意見変 動に及ぼす影響を検証していくことは重要であろ う。

本研究における教員への調查はあくまで自己評 価であり, かつ, 各クラスの賛否の変容について も，偶発的に生じた結果である可能性を完全には 否定できない。しかし，もし，講義中に表には出 していないはずの教員の経験や考え, 講義スタイ ルが受講者の考えに影響を及ぼしたのであれば, 本研究のような答えのない論争的問題を取り扱う 教育においては, 特に, その教授法を改善し続け る必要があるだろう。

\section{6. まとめ}

本研究では, 2018 年度に開講した科目「シチズ ンシップ」で得られた結果を元に, 原発再稼働賛 否意見の変容に対する受講者の専門性や学習状 況, 及び講義担当教員の意識の影響について検討 し, 以下の結果を得た。

（1）受講者全体の意見変動については, 第 1 講か ら第 3 講にかけて, 賛成割合が単調増加し, 反対割合が単調減少した（第 1 講の最初：賛 成 $25 \%$ • 反対 $75 \%$, 第 3 講の最後: 賛成 $57 \%$. 反対 $43 \%$ )。

（2）受講者全体の意見変動の理由について，反対 理由「とにかく安全面で信用できないから」 から賛成理由「安全性の問題はあるが，原発 に頼る他方法がないから」を選択した受講者 が最も高い割合で約 40.9\%であった。賛成理 由「安全性の問題はあるが, 原発に頼る他方 法がないから」から反対理由「太陽光などの 再生可能エネルギーでもっと賄えると思うか ら」を選択した受講者が最も高い割合で $32.8 \%$ を占めた。

(3) 3 回分の講義を通じた賛成・ 反対意見の変化 の度合い（標準偏差：S）は学科により異な り, 不確定性はあるものの $\mathrm{W}$ 学科と X 学科 のような理系を中心に学ぶ学科は小さい傾向 にあり ( $\mathrm{W}$ 学科 $\mathrm{S}=7.5, \mathrm{X}$ 学科 $\mathrm{S}=7.3$ ), 大 学入学時のプレースメントテスト (英語) の 平均点が高い学科 (学習経験が豊富な学生が 在籍しているであろう学科) ほど, 標準偏差 が小さい傾向にあった $(r=-0.438)$ 。

（4）原発再稼働については明確な反対意見をもっ ている教員 $E$ のクラスについては, 賛成と反 対の割合が交差せず $(S=5.3)$, 常に反対割合 が高い状態を維持していた。また，講義内容 を力を込めて説明する傾向がある教員 $A$ のク ラスは, 受講者の賛否変異が大きい $(\mathrm{S}=16.6)$ 傾向にあった。

（5）このように, 受講者の専門性や学習経験, 教 員の意見, および講義スタイルによって, 受 講者の原発再稼働に対する意見に影響する可 能性があることを明らかにした。以上のこと から, 論争的問題を取り扱うシティズンシッ 
プ教育においては，これらの影響因子を考慮 に入れた教授法についてさらに検討する必要 がある。

\section{注}

1) citizenship は一般的に「シティズンシップ」や 「シチズンシップ」とカナ読みされ, 論文等では前 者を採用したものが比較的多い。京都光華女子大学 の科目名としては運用便宜上の理由から後者を採 用している。

2 ）バックエンドコストとは, 原発を動かした後に発 生する使用済み核燃料の再処理や廃棄，さらに原子 力発電所の解体に係る費用のこと。

\section{引用文献}

青木秀和 (2016)「日本の電力事業における発電部 門別収支の研究」『財政と公共政策』第 38 巻第 1 号, 52-67.

Department for Education and Employment (1998) Education for citizenship and the teaching of democracy in schools: Final report of the Advisory Group on Citizenship: Qualifications and Curriculum Authority, pp.11-13.

速水多佳子 (2016)「高等学校家庭科における住居 領域の授業実践－指導者の違いに着目してー」 『日本家庭科教育学会第 59 回大会』B2-1.

今井照 (2016)「原発災害被害者の実態調査（5 次)」『自治総研通巻』450号 4 月号, pp.1-33. 乾明紀・高野拓樹 (2017)「論争的問題を導入した 主権者教育の試み -2016 年度 京都光華女子 大学初年次必修科目「シチズンシップ」の取組 み-」『京都光華女子大学・京都光華女子大学短 期大学部研究紀要』第 55 号, pp.11-20.

片岡佳美・吹野卓（2015）「島根原子力発電所立地 地域住民の原発に対する意識の分析」『山陰研 究』第 8 号, pp.37-46.

小玉重夫（2016）「教育政治学を拓く 18 歳選挙権 の時代を見すえて」勁草書房, pp.177-188.

小島一記・重田勝介 (2017)「科学的リテラシーに おける態度の変容に効果的な授業の要因の検 討」『日本科学教育学会研究会研究報告』第 32 巻第 1 号, pp.21-24.

岡本紗知（2016）「日本の大学生は「科学の本質」 を適切に理解しているか」『日本科学教育学会研
究会研究報告』第 31 巻第 4 号, pp.67-72.

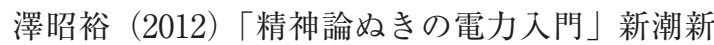
書, pp.21-115.

高野拓樹 (2016)「地球環境クライシス -未来へつ

なぐ命のバトンー」ムイスリ出版, pp.114-115. 高野拓樹・乾明紀・朝倉眞一・久保友美 (2017)

「アクティブラーニング手法を用いた環境・エネ ルギー教育の実践〜原発再稼働の是非を事例と

して〜」『日本環境学会第 43 回研究発表会発表 予稿集』pp.66-67.

高野拓樹 ・ 乾明紀 · 加藤千恵・酒井浩二 (2018a)

「原発再稼働賛否の意思決定プロセス - 論争的 問題を導入したシティズンシップ教育の試み 一」『人間と環境』第 44 巻第 3 号, pp.18-28.

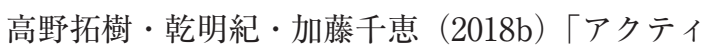

ブラーニング手法を用いた環境・エネルギー教 育の実践〜学生の専門性の違いにみる原発再稼 働賛否に関する意見変化〜」『日本環境学会第 44 回研究発表会発表予稿集』pp.38-39.

竹内裕一 (1994)「態度変容をめざした社会科授業

構成およびカリキュラム構成原理試案」『千葉大 学教育学部研究紀要』第 42 巻第 1 号, pp.239252.

上園昌武·江口貴康 ·関耕平 (2012)「島根原発稼 働への松江市民の意識構造」『山陰研究』第 5 号, pp.1-18.

和田武（2016）「再生可能エネルギー $100 \%$ 時代の 到来」あけび書房, pp.21-75.

渡部竜也 (2016)「我が国のベテラン社会科教師の 授業分析に見られるコレクトネス：教育学者・ ベテラン教師 7 人の授業批評に見られる分析視 点の違いから」『東京学芸大学紀要 人文社会科 学系 II』第 67 巻, pp.1-33.

八ッ橋武明 (2013)「原発再稼働賛否に見る社会意 識－試論」『情報研究』第 48 号, pp.49-61. 横山悟 (2016)「入学試験区分による経時的デー夕 に基づいた大学初年次学生の英語力の分析」『千 葉科学大学紀要』第 9 巻, pp.9-16.

復興庁 (2019)「避難者の数 [令和元年 10 月 29

日]」https://www.reconstruction.go.jp/topics/ main-cat2/sub-cat2-1/20191029_hinansha.pdf, 2019 年 11 月 2 日閲覧.

産経新聞（2019）「【東日本大震災 8 年半】福島 · 
避難指示自治体の帰還率は 3 割未満 放射線へ の不安背景に」https://www.sankei.com/life/ news/190910/lif1909100026-n1.html, 2019 年 11 月 2 日閲覧.

資源エネルギー庁（2016a）「電源種別（太陽光・ 風力）のコスト動向等について」https://www. meti.go.jp/shingikai/santeii/pdf/025_01_00. pdf, 2019 年 4 月 23 日閲覧.

資源エネルギー庁（2016b）「長期エネルギー需給 見通し小委員会に対する発電コスト等の検証に関 する報告」https://www.enecho.meti.go.jp/ committee/council/basic_policy_subcommittee/ mitoshi/cost_wg/006/pdf/006_05.pdf, 2019 年 4 月 23 日閲覧.
資源エネルギー庁 (2017)「エネルギー情勢を巡る 状況変化」https://www.enecho.meti.go.jp/ committee/studygroup/ene_situation/001/ pdf/001_005.pdf, 2019 年 3 月 20 日閲覧.

資源エネルギー庁（2018a）「2030 年エネルギー ミックス実現へ 向けた対応について〜全体整理 〜 https://www.enecho.meti.go.jp/committee/ council/basic_policy_subcommittee/ 025/pdf/025_008.pdf, 2019 年 4 月 23 日閲覧.

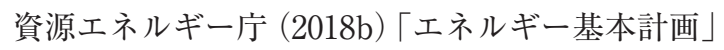
https://www.meti.go.jp/press/2018/07/ 20180703001/20180703001-1.pdf, 2019 年 3 月 20 日閲覧.

(2019 年 11 月 6 日受付, 2020 年 3 月 27 日受理) 